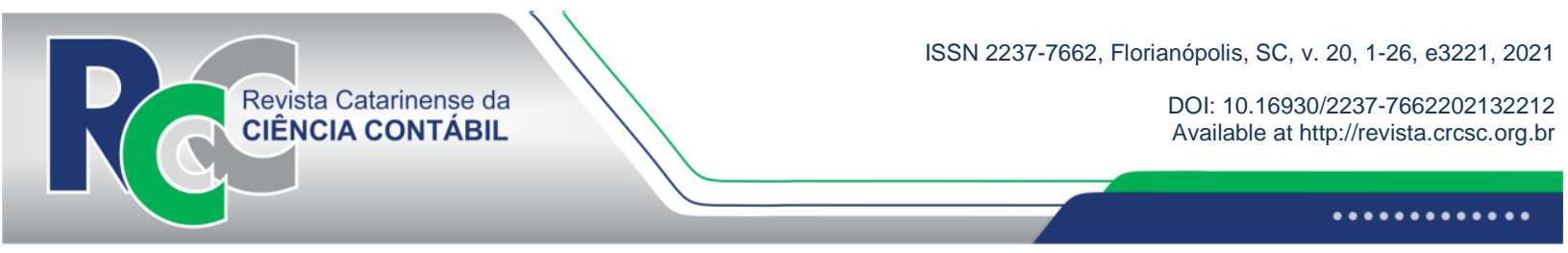

\title{
INSTITUTIONAL VARIABLES EXPLAINING THE PERFORMANCE OF ACCOUNTING AND ADMINISTRATION STUDENTS
}

\author{
VITOR HIDEO NASU \\ University of São Paulo. Address: Av. Prof. Luciano \\ Gualberto, 908 | Butantã | 05508-010 | São Paulo/SP | \\ Brazil. \\ (D) https://orcid.org/0000-0002-5176-6634 \\ vnasu@usp.br
}

\section{BRENO GABRIEL DA SILVA}

University of São Paulo. Address: Av. Pádua Dias, 235 | Agronomia | 13418-900| Piracicaba/SP | Brazil.

(1) https://orcid.org/0000-0002-8322-9235

brenogsilva@usp.br

\author{
YANA MIRANDA BORGES \\ Federal Institute of Education, Science and Technology of \\ Amazonas. Address: Av. Sete de Setembro, 1975 | Centro | \\ 69020-120 | Manaus/AM | Brazil. \\ (D) https://orcid.org/0000-0002-1866-5524 \\ borges.yana@gmail.com
}

BRIAN ALVAREZ RIBEIRO DE MELO

State University of Maringá. Address: Av. Colombo, $5790 \mid$ Jd. Universitário | 87020-900| Maringá/PR | Brazil.

(1) https://orcid.org/0000-0002-8217-114X

brian.rmelo@gmail.com

\begin{abstract}
The aim of this study was to analyze the association between institutional variables and the performance of Accounting and Administration students. The microdata of Enade 2018 were used, obtaining 152,491 valid observations. Performance was measured in three ways: final performance, performance in the general training test and performance in the specific component test. In addition, the following institutional variables were considered: academic organization, region, modality and shift. The data were examined using zero adjusted Box Cox Cole Green (BCCG) regression models. The results indicated the institutional variables were relevant to explain the performance. Specifically, it was staked students enrolled in federal centers of technological education had superior performance than the other forms of academic organization. Another relevant point was the students in the North region performed worse than other regions in general. However, they outdid the students from Central-East region in the issues of general training. Regarding the teaching modality, it was found that students of face-toface teaching presented higher performance than the distance learning students (DL). And the full-time students had better performances overall. As implications, it is pointed out that institutions offering Accounting and Administration courses in the Northern region may want to improve the quality of education, as well as those of the Centre-Western shall want to do so in relation to general training education. Similarly, the teaching on the DL modality can be improved and the offer of full-time courses can be thought of and potentially implemented.
\end{abstract}

Keywords: Institutional variables. Academic performance. Learning. Business. BCCG.

Edited in Portuguese and English. Original version in Portuguese.

Received on 11/3/2021. Revised on 12/13/2021. Accepted on 12/14/2021 by Prof. Dr. Sérgio Murilo Petri (Editor-in-Chief) and Prof. Dr. Sandro Vieira Soares (Associate Editor). Published on 12/23/2021.

Copyright $\odot 2021$ RCCC. All rights reserved. It is allowed to quote part of articles without prior authorization, provided that the source is identified. 


\section{INTRODUCTION}

Student performance is an important academic construct because it provides an indication of student learning. Its measurement is one of the fundamental points for determining who advances or who repeats the discipline, to whom the scholarship should be conceived, to whom exchange vacancies are allocated, who enters graduate school and so on. Academic performance is used as a selection criterion for a series of institutional activities and policies and can also be used in curriculum analysis in job interviews. Usually, students with better-qualified school historical backgrounds tend to get such advantages.

Measuring student performance is also useful and necessary to verify progress and declines in learning over time. Teaching and discipline measures may apply to students depending on what the analyses of their performance allow them to conclude. Miranda, Lemos, Oliveira and Ferreira (2015) note there are different measurements of student performance, including the grade of an exam, the grade of a discipline, the average score of the period, the overall average accumulated pure or adjusted and external evaluations to educational institutions. Regardless of the measure of performance used, the aim is to evaluate the capacity demonstrated by the student in performing a certain task based on well-defined criteria.

Due to its relevance and usefulness in the educational area, researchers seek to understand which and how variables are associated with student performance in order to optimize it (Ahinful, Tauringana, Bansah \& Essuman, 2019; Byrne \& Flood, 2008; Caetano, Cardoso, Miranda, \& Freitas, 2015; Nasu \& Sasso, 2021; Rodrigues, Miranda, Resende, \& Pereira, 2016). Understanding the factors associated with academic performance can help students, faculty, academic directors, and educational policymakers implement or adjust policies, practices, and pedagogical plans to increase student learning.

In the business area, the variables that determine student performance can be classified into three major groups: student body (SB); teaching staff (TS); and the higher education institution (HEI) (Miranda et al., 2015; Rodrigues et al., 2016). In the SB group there are the student' variables, such as gender, age and marital status. In the TS group, variables such as entitling, work regime and professional experience of the teacher are comprised. Lastly, in the HEI group there are variables related to the institution, including study environment, infrastructure, and time of the course, for example. Soares's study (2004, p. 96) shows that even the variables of safety ("existence of items in the school such as: help of the police, walls and protective fences, control of entry and exit of students and other people, signs of depredation") and cleaning of the school ("index assigned by the applicator of the test to the cleaning of classrooms, bathrooms, recreation areas and external areas") can influence the performance of the student.

In the fields of administration and accounting (under a broader umbrella called the "business area"), professionals deal with various sectors within companies and need to have an overall view of their operation for appropriate decision making. Consequently, your academic background needs to be solid in such a way that this holistic business perspective is absorbed by the student. Therefore, professors of business courses have strong motivation to continue analyzing the performance of their students and related variables. In Byrne and Flood's (2008) view, the more information about the factors associated with academic success or failure, the better prepared educators are to support and guide their students. Hence, monitoring of the student's learning, reflected in their academic performance, is crucial for its improvement.

Substantial efforts have been made to understand the variables associated with the performance of business students (Byrne \& Flood, 2008; Caetano et al., 2015; Gracia \& Jenkins, 2003; Mallmann, Nasu \& Domingues, 2021; Nasu \& Sasso, 2021; Pike, 1991; Rodrigues et al., 2016). However, while there is a strong concentration of studies investigating the variables of the 
SB and TS groups, there is a lack of research examining institutional variables (HEI group) (Miranda et al., 2015). Consequently, the present study aims to analyze the association between institutional variables and the academic performance of students in the business area (Administration and Accounting). More specifically, this study is interested in the following variables related to HEI: academic organization, geographic region, teaching modality and course shift.

Though the variable analysis of the SB and TS groups provide a more micro view of how student performance is affected, the investigation of variables in the HEI group allows us to see the academic performance from a more macro perspective. Institutional variables support the student during their educational process because they represent the infrastructure of the classrooms, the institution's facilities, the materials and resources available (Miranda et al., 2015). In addition, the HEI may present strategic academic locations and organizations to draw students in. Similarly, they can offer courses in different shifts and regions to pluralize access to knowledge by potential students. In their interest, the students can choose how they wish to study so they are able to reconcile, satisfactorily, their academic life with their personal and working life. Thus, examining institutional variables brings complementary findings to the previous literature.

The contribution of this work rests on three main points. First, it is argued that the investigation of institutional variables is relevant because it promotes changes in the level of HEI, which, in turn, might help not only business courses but also undergraduate courses in general. Understanding institutional factors which bases the educational process contributes to increase their performance. The advance proposed by this article is a better understanding of academic performance in a more contextualized way. The variables of the SB and TS groups refer to students and teachers in their specific teaching and learning conditions. When examining the variables of the HEI group, the contextual component is added. Second, this work provides methodological contribution. Unlike studies on academic performance using traditional regression models (i.e., linear via ordinary least squares), the zero adjusted Box Cox Cole Green (BCCG) regression model was suitable for this data analysis, as discussed below. Future studies can use this technique when their data sets are similar to this study, especially those related to the analysis of student performance in Enade, whose database served as the basis for this study, as found in the methodological section. Third, Miranda et al. (2015) realized "there were few studies that related educational institutions, their infrastructure or their school organization. Moreover, the results were quite divergent, precluding to make conclusions about the results presented"(p. 198). The authors of the present study saw this lower number of studies on the variables of HEIs and conflicting findings as an opportunity to contribute to the body of evidence obtained so far.

The rest of the article is organized as follows: section 2 brings the theoretical framework, in which research is discussed and reasoning is drawn about student performance and institutional variables; section 3 describes the methodological procedures and decisions of the research, focusing on the description of the database and analysis technique; section 4 reports the results and establishes conversation with the previous literature; and section 5 discusses the conclusions, implications, limitations and suggestions for future investigations.

\section{THEORETICAL FRAMEWORK}

\subsection{Student performance and SB, TS and HEI groups}

According to Miranda et al. (2015), the variables related to the academic performance of business students can be classified into three major groups: SB, TS and HEI. In the SB group, the concern is to examine how the student's variables are associated with their performance. For 
example, Ahinful et al. (2019) found evidence that motivational factors (expectation and volition), engagement and commitment (academic interest and learning attitude) significantly influenced the performance of accounting students. In another study, Stice, Stice and Albrecht (2020) investigated how students' study choices were associated with their performance and found that students who read texts had better performances than those who watched videos as a learning strategy. The characteristics evidenced by these studies refer to the students and, therefore, are categorized in the SB.

In the TS group, research focuses on the relationship between teacher variables and student performance. Westerman, Whitaker, Bergman, Bergman and Daly (2016) analyzed the narcissism of professors and students in the business area and found that narcissism is significantly associated with the final grade of students. In particular, it was found that narcissistic professors are related to lower grades obtained by less narcissistic students. The TS also includes the teaching strategies used by teachers. In this regard, research has tested multiple pedagogical techniques aimed at increasing student performance, such as games and gamification (Beatson et al., 2020; ElKelish \& Ahmed, 2021; Kuang, Adler, \& Pandey, 2021), technology (Francescucci, Kellershohn, \& Pyle, 2021; Namin, Ketron, Kaltcheva, \& Winsor, 2021), instructional case study (Cheng, Sapkota, \& Yurko, 2021), narratives (Grimm, 2021; Taylor, Marrone, Tayar, \& Mueller, 2017), type, frequency and evaluation policies (Miglietti, 2021; Nakos \& Whiting, 2018; Nsor-Ambala, 2020) and so on. In the case of the HEI group, the purpose is to verify how variables of educational institutions are associated with academic performance. In this group, Miranda et al. (2015) include technological resources, classroom infrastructure, teaching resources and facilities. Kafaji (2020) aimed to analyze the benefits perceived by students about accreditation of private business schools and their relationship with students' performance, motivation and career prospecting. Through structural equation modeling, it was found that accreditation has a positive association with student performance.

Compared to SB and TS, the HEI group has a lower occurrence of studies (Miranda et al., 2015). Potentially, this is because there is a more direct view of the relations between academic performance and student and teacher variables. When it comes to the institution, this perception is less immediate. Not so, efforts should cease to be made. On the contrary, the lower occurrence of research denotes that there is room for relevant contributions to the literature of academic performance in the business area departing from analyses of institutional variables. This can provide grants to better guide the choice of the type of HEI and the course by future entrants. Academic performance should therefore be observed and monitored from the three perspectives, as illustrated in Figure 1 


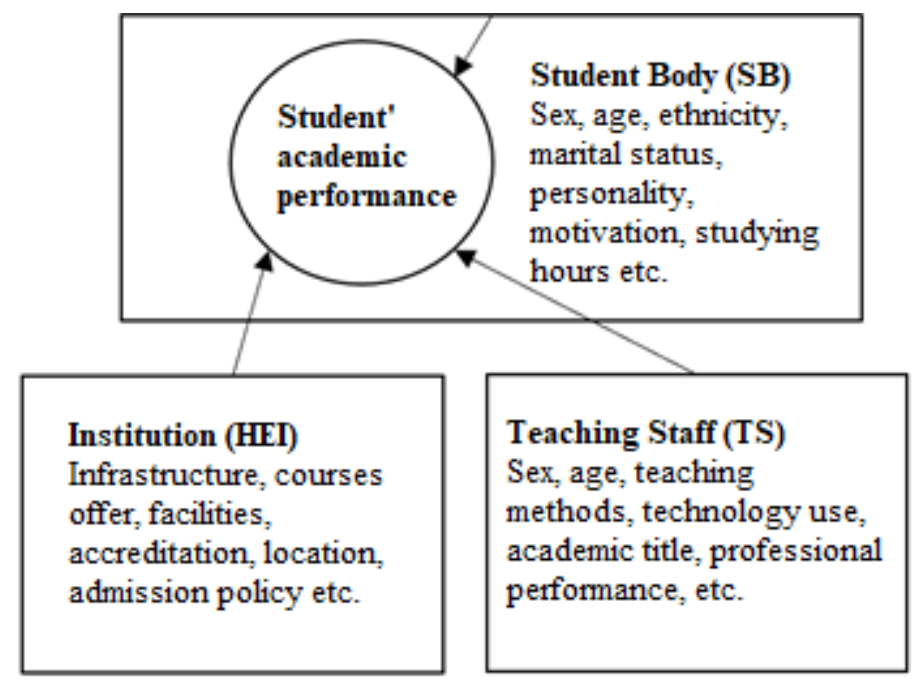

Figure 1. Determinants of academic performance

Source: Prepared by the authors based on Miranda et al. (2015).

In addition to SB and TS variables, future investigations on academic performance may include those of the HEI group in their analysis models to obtain more complete findings. In this research, only institutional variables are focused. We examined the relationship between student performance and academic organization, region, teaching modality and course shift.

\subsection{Institutional variables}

According to Fogarty, Zimmerman and Richardson (2016), HEIs play two central social roles. The first is to educate society and the second is to produce new knowledge. In the role of the population education, the HEIs achieve this goal by preparing their students for the chosen professional activity. In the case of the expansion of knowledge, the HEI usually achieve this end when developing research. Although academic performance may be more directly related to the first social performance, there are relevant proposals for integrating research into teaching as a way to improve student learning (Madsen, 2020). Thus, the way HEIs are organized and offer courses can influence the performance of your students.

Institutional variables are characteristics that are more associated with HEI, rather than students and teachers. In this research, emphasis is placed on academic organization, regionality, teaching modality and shift. Starting with the academic organization, Baldo (2018) discusses the forms of organization that HEI can take in Brazil. First, the author highlights the universities, characterized by their multidisciplinary performance and by the indissociability of teaching, research and service, in addition to didactic-scientific autonomy. In the case of university centers, research activity is not mandatory (Baldo, 2018), but there is autonomy similar to that of universities. The colleges, in turn, are HEIs that offer one or more higher courses, but do not have autonomy and for this reason the Ministry of Education must authorize to open or close courses, increase or decrease the number of vacancies, among other processes. Higher education institutes (HEI) are those that "object the teaching of basic education through initial, continuous and complementary formation" (Baldo, 2018, p. 12). Finally, there are the technological education centers and federal centers of technological education (Cefets) that work in postsecondary professional education with the purpose of professional qualification at multiple educational levels and through different modalities of education, serving as a mechanism of continuing education (Baldo, 2018).

The work of Bervian and Corrêa (2015) analyzed the performance of students of administration of universities, university centers and colleges and found no relevant difference. 
In the work of Caetano et al. (2015), university students achieved better performances than students from other types of HEI. Santos (2012) investigated the determinants of academic performance from Accounting students, including the academic organization of the HEI. This variable was measured as follows: 1 for universities and university centers and 0 for integrated colleges, colleges, schools and higher institutes, education and technology centers. The results showed that, for "Provão" 2002, the academic organization was not meaningful. However, it was significant in "Provão" 2003 and Enade 2006, in which students from universities and university centers obtained better performances. Considering the different characteristics assumed in each type of academic organization and the empirical findings described, the first hypothesis of this research is formulated as follows:

H1: There is a significant difference between the performance of students enrolled in different forms of academic organization.

The HEI and/or undergraduate region has been the most frequent target of academic research involving student performance and is essential because they can show substantial discrepancies in student performance regionally (see, for example, Brandt, Tejedo-Romero \& Araujo, 2020; Mallman et al., 2021; Nasu \& Sasso, 2021; Santos, 2012). Thus, it is possible to verify if some region has a more deficient education in relation to the other ones and how this can be adjusted. The analyses of Nasu and Sasso (2021) indicated that the performance of students of courses in the business area on the North region of Brazil was materially higher than those from the South region, lower than those from the Northeast and Southeast regions and close to those of the Central-West region. In the case of the study made by Mallmann et al. (2021), in which the performance of students in Applied Social Sciences was examined, it was found that the students from the Southeast region had significantly higher performances compared to those from the other regions. Likewise, using data from Public Administration students, Brandt et al. (2020) found that those registered in the Southeast region outnumbered those of the other regions. In the study of Santos (2012) it was found that students from the South and Southeast regions (categorized as 1) obtained higher performance than the ones from the other regions (categorized as 0). This evidence suggests that the region in which the $\mathrm{HEI} /$ course is located may have a relevant effect on the performance of the students. Santos, Pales and Rodrigues (2014) highlight the inequalities of Brazilian regions based on historical socioeconomic data (1991-2010), noting that the North and Northeast regions are the most disadvantaged. Data from the National Continuous Household Sample Survey ("PNAD Continuada") - Educação 2019, prepared by the Brazilian Institute of Geography and Statistics (IBGE, 2019), also show that the North and Northeast regions present the most unfavorable situations educationally. Based on this historical scenario, the second hypothesis is presented as follows:

H2: The North and Northeast regions are negatively associated with academic performance.

The influence of the teaching modality on student performance has been attracting the attention of researchers, particularly in the last two decades, in which there was an acceleration of technological advances that enabled new ways of generating and disseminating content, and also giving rise to new modalities of formal education (as discussed in Caetano et al., 2015; Fortin, Viger, Deslandes, Callimaci \& Desforges, 2019; McCarthy, Kusaila \& Grasso, 2019; Rodrigues et al. 2016; NASU 2020; Santos, 2012). In this context, Rodrigues et al. (2016) investigated the determinants of academic performance of distance learning (DL) Accounting 
students and found that the variables of the SB group were the most influential. Similarly, Nasu (2020) found that the sociodemographic factors of the students were also relevant. In a study conducted with students from the disciplines "Intermediate Accounting III and Audit", McCarthy et al. (2019) found evidence that academic performance was similar when considering the modalities in person, hybrid and online. Fortin et al. (2019) examined the format of the hybrid teaching modality and its relationship with student performance and satisfaction. Specifically, two hybrid modalities were analyzed: F2F+ (course with predominantly face-toface classes) and Online+ (course with predominantly online classes). It was noticed through the results that the students performed similarly in both hybrid teaching formats. The findings of Caetano et al. (2015) show that classroom students scored better than those in DL. Similarly, their level of satisfaction was similar. These results support that the teaching modality can be significantly connected to academic performance. The rapid expansion of higher education through the DL has raised questions about its quality (Alonso, 2010; Bertolin, 2021). Bertolin (2021) notes there is a distinction in quality between face-to-face and distance teaching, where the first is of the highest quality. In the area of accounting, evidence suggests that employers (companies) prefer to hire employees who studied in person (Grossman \& Johnson, 2016), even when they themselves have completed the undergraduate course in the DL format (Grossman \& Johnson, 2017). Thus, the third hypothesis is formulated as follows:

H3: The modality of classroom teaching is positively associated with academic performance.

The last institutional variable investigated by this research is the course shift. This aspect, at first sight, may not seem to be associated with student performance, but it is a reflection of important learning conditions. Andreoli and De Martino (2012) gathered evidence that the patterns of college students in the morning shift were relevantly different from the ones of the night shift and that those performance (morning-shifted) was higher than these (night-shifted). The findings of the research by Farias, Alves and Farias (2015) also support that day shift students (morning and afternoon) have significantly better performances than those of the night shift. In the research of Mallmann et al. (2021) it was found that full-time students performed better than those in the morning, afternoon, and night shifts. This finding is consistent with expectation, since this type of shift requires students to devote themselves to full-time studies. In turn, Moura, Miranda and Pereira (2015) found that accounting science students from the Federal University of Uberlândia (UFU) of the night shift had better performances compared to the full shift. Consistently, UFU stated that night students tend to perform better than integral students. This result may be related to specific characteristics of the context investigated, since it is a counterintuitive finding. Furthermore, there is evidence that performance is not significantly associated with the shift (Cornachione Junior et al., 2010). Although empirical findings present a certain degree of conflict, it seems reasonable to expect full-time students to get better performances. As noted by Cornachione Junior et al. (2010), it is typical that students in the business area of the night shift work during the day and study at night. Therefore, there is less amount of study hours available in comparison with the students from the full shift or even the morning or afternoon shifts. Thus, the fourth hypothesis of the survey is reported as follows:

H4: The full shift is positively associated with academic performance.

It is emphasized that other institutional variables exist and their insertion in the models of analysis of future research is encouraged. However, considering its lower appearance, especially in relation to variables of the SB and TS groups, this work strengthens the literature from the 
focus on academic organization, region, teaching modality and shift. Gradually, other variables can be considered.

\section{METHODOLOGY}

The present study used the microdata of the National Student Performance Exam (Enade 2018), which were collected from the website of the National Institute of Educational Studies and Research Anísio Teixeira (INEP, 2021). It should be noted that Enade 2018 was the last edition held by Business and Accounting students whose data are available. It is pertinent to indicate that the final grade of the Enade student is composed of $25 \%$ of their performance in the general training test (issues involving general themes, such as social responsibility and globalization) and $75 \%$ in the specific component test (specific issues of each course). In this study, the three forms of student performance measurement were taken into account.

After the collection, the variables of interest on this study were selected from the ones available by Enade, as specified in Table 1 Academic performance was measured in three ways: final performance (FP), performance in the general formation test (PGF) and performance in the specific component test (PSC). In the case of institutional variables, the academic organization (AO), geographic region (REG), teaching modality (MOD) and course shift (SHI) were considered. Once such variables were selected, the presence of missing values and NAs was observed. These cases were excluded, with a total of 152,491 observations remaining $(83.38 \%$ of the total).

Table 1

Variables of the study

\begin{tabular}{|c|c|c|}
\hline Acronym & Description & Measurement \\
\hline FP & Final performance & 0 to 100 points. \\
\hline PGF & $\begin{array}{l}\text { Performance in the general } \\
\text { formation test }\end{array}$ & 0 to 100 points. \\
\hline PSC & $\begin{array}{l}\text { Performance in specific } \\
\text { component test }\end{array}$ & 0 to 100 points. \\
\hline $\mathrm{AO}$ & Academic organization of HEIs & $\begin{array}{l}\text { University; College; University Center (CUniv); Federal } \\
\text { Institute of Education, Science and Technology (IF); Federal } \\
\text { Center for Technological Education (Cefet). }\end{array}$ \\
\hline REG & Geographic region & North; Northeast; Midwest; Southeast; South. \\
\hline MOD & Teaching modality & Face-to-face; Distance Learning (DL). \\
\hline SHI & Shift & Morning; Afternoon; Night; Full-time. \\
\hline
\end{tabular}

Then, the analysis technique was chosen. At first, exploratory data analysis was performed, focusing on descriptive statistics and histograms. TableTable 2the mean, median, standard deviation, minimum and maximum of performance variables. When observing the means, it is noticed that the performance was relatively low, given that the interval of the notes was from 0 to 100 points. The mean FP was 37.88 points, indicating that, in general, the students performed below half (50 points) of the possible score. Evaluating the performance by type of test, it is noted that the students obtained better performance in the general education test (mean $=42.80$ ) compared to the performance in the specific knowledge test (mean $=36.22$ ). This finding makes evident the importance of strengthening the specific knowledge of the student in relation to the chosen profession. In this case, the counter or administrator. The minimum values also represent indications that students' knowledge can be improved, since there was at least one observation that obtained a zero score. 
Table 2

Descriptive statistics of student performance

\begin{tabular}{cccccc}
\hline Quantitative variables & Average & Median & Standard deviation & Minimal & Maximum \\
\hline FP & 37,88 & 37,1 & 12,96 & 0 & 92,8 \\
PGF & 42,80 & 42,3 & 16,59 & 0 & 96,4 \\
PSC & 36,22 & 35,6 & 14,06 & 0 & 95,2 \\
\hline
\end{tabular}

Table 3 shows the absolute and relative frequencies of the variables related to HEI. It is noteworthy that most students who did Enade 2018 were enrolled in universities $(48.80 \%)$, were from the Southeast region $(43.49 \%)$, studied in the face-to-face mode $(76.00 \%)$ and were nightshifted $(82.39 \%)$. On the other hand, Cefet $(0.10 \%)$, North region $(4.74 \%)$, Distance Learning (24\%) and afternoon-shifted (1.22\%) are the categories with the lowest frequency. This description is compatible with what is expected, since the typical business student tends to be from the night period course (mainly due to work), the Southeast region (largest population) and the classroom teaching of universities (greater number of vacancies). These characteristics were perceived by previous research (Cornachione Junior et al., 2010).

Table 3

Frequencies of institutional variables

\begin{tabular}{lcc}
\hline Qualitative variables & Absolute frequency & Relative frequency \\
\hline AO - Cefet & 148 & 0,10 \\
AO - CUniv & 33.586 & 22,02 \\
AO - College & 43.442 & 28,48 \\
AO - IF & 897 & 0,58 \\
AO - University & 74.418 & 48,80 \\
REG - North & 7.220 & 4,74 \\
REG - Northeast & 25.457 & 16,69 \\
REG - Southeast & 66.326 & 43,49 \\
REG - South & 42.163 & 27,64 \\
REG - Central-West & 11.325 & 7,42 \\
MOD - Face-to-face & 115.904 & 76,00 \\
MOD - Distance Learning & 36.587 & 24,00 \\
SHI - Morning & 13.116 & 8,60 \\
SHI - Afternoon & 1.870 & 1,22 \\
SHI - Full-time & 11.854 & 7,77 \\
SHI - Night & 125.651 & 82,39 \\
\hline
\end{tabular}

Afterwards, the histograms of the performance variables are reported in Figure Figure 2 The histograms of the left, center and right are, respectively, referring to the variables FP, PGF and PSC. It is noticed in the three notes there is occurrence of zeros, represented by the vertical line with the red dot at the top and the distributions are approximately symmetrical. This symmetry indicates that a normal model may be suitable in modeling notes. However, when performing the Shapiro-Wilk tests, it was found that the grades are not normally distributed ( $\mathrm{p}<$ 0.05). For this reason, it was verified that conventional regression models (i.e.: linear via ordinary least squares) were not adequate for this data set. 

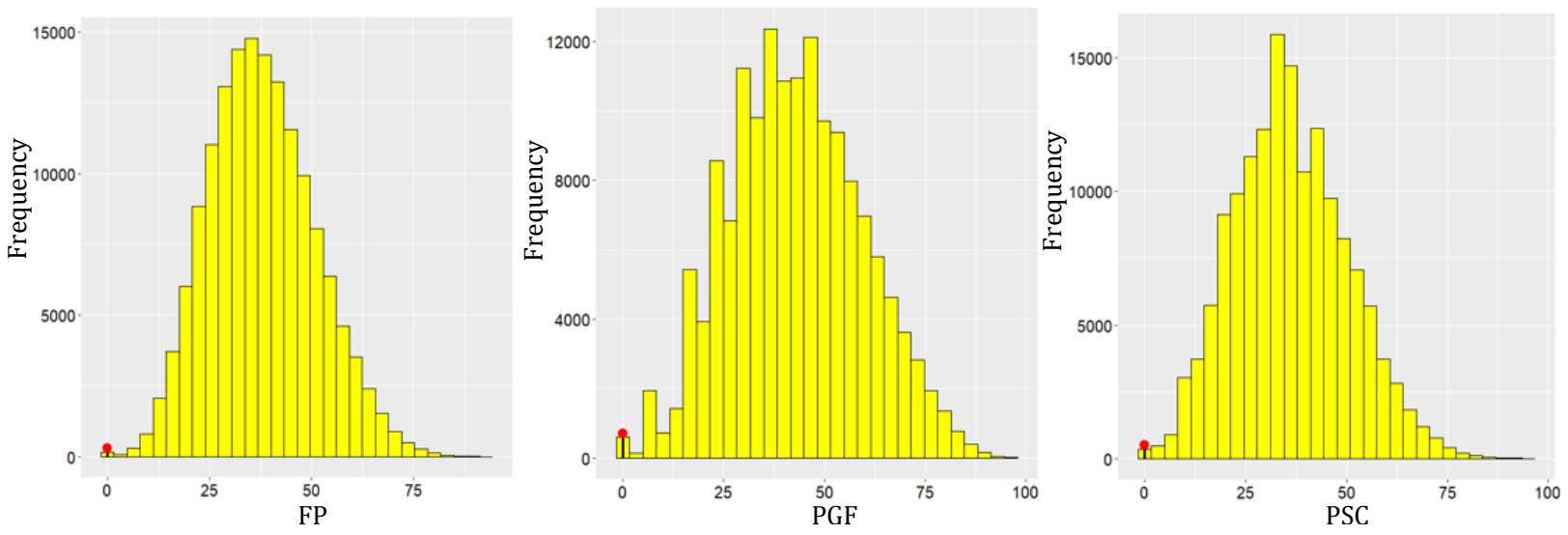

Figure 2. Histograms of student performance variables (FP, PGF and PSC) Source: Search data.

In view of these results, it was necessary to resort to another type of modeling that accommodated both the excess of zeros and the symmetry of the distribution of positive notes. An alternative is the use of mixing models (Stasinopoulos, Enea, \& Rigby, 2017), which have a discrete-continuous mixing density function of the form specified in Equation (1):

$$
f_{y}(y \mid \boldsymbol{\theta}, \xi)=\left\{\begin{array}{l}
\xi, \text { se } y=0 \\
(1-\xi) f_{W}(y \mid \boldsymbol{\theta}), \text { se } 0<y<\infty
\end{array}\right.
$$

in which $0 \leq y<\infty$ represents the support of the response variable (FP, PGF and PSC); $f_{W}(y \mid \boldsymbol{\theta})$ represents some continuous probability density function defined in the range with $(0, \infty)$ parameters $\boldsymbol{\theta}^{T}=\left(\theta_{1}, \theta_{2}, \ldots, \theta_{p}\right)$ and, finally, $0<\xi<1$, where $\xi=P(Y=0)$ is the probability of occurrence of zero (Stasinopoulos et al., 2017). Thus, for the part referring to zeros, binomial modeling is used and for the continuous part, it was necessary to find a distribution that fits appropriately to the continuity of the data.

One of the ways to find such distribution was using Generalized Additive Models for Rental, Scale and Shape (GAMLSS). The ChooseDist () function of the gamlss package (Stasinopoulos et al., 2021) was used to obtain the candidate distributions for modeling the continuous part of the dependent variables (FP, PGF and PSC). To choose the most appropriate distribution, the widespread Akaike Information Criterion (AIC) was considered. For the three dependent variables, the most adapted distribution to the continuous part of the data was BCCG.

Therefore, $Y \sim \operatorname{ZABCCG}(\mu, \sigma, v, \xi)$ refers to a zero-adjusted BCCG distribution of $0<\mu<\infty$ parameters, $0<\sigma<\infty,-\infty<v<\infty$ and, $0<\xi<1$ in which $0 \leq y<\infty$ and $\sim \operatorname{BCCG}(\mu, \sigma, v) . W$, therefore, follows a BCCG distribution of parameters $(\mu, \sigma, v)$ (Rigby, Stasinopoulos, Heller, \& De Bastiani, 2019). The binding function used for $\mu$ and $v$ is the identity, for $\sigma$ is the $\log$, and for $\xi$ is the log. It should be noted that, depending on the quality of the adjustment, other binding functions may be employed. In this study, however, it was not necessary since the quality of the adjustment was satisfactory. Equation (2) reports the probability density function $f_{W}(y)$ when $v \neq 0$ :

$$
f_{w}(y \mid \mu, \sigma, v)=\frac{y^{v-1} \exp \left(-\frac{1}{2} z^{2}\right)}{\mu^{v} \sigma \sqrt{2} \pi \Phi\left[(\sigma \mid v)^{-1}\right]^{\prime}}
$$


Where $\Phi(.)^{-1}$ denoting the inverse of the cumulative distribution function of the Normalstandard distribution and $\mathrm{z}$ is a constant defined by $-\frac{1}{\sigma \nu}<z<\infty$ to $v \neq 0$ or $-\infty<z<-\frac{1}{\sigma \nu}$ from $v<0$. Once the distributions for data modeling and the binding functions of each parameter were defined, the zero adjusted BCCG regression model was formulated (Equations (3), (4) and (5)), including the estimation $\xi_{0}$ of (Equation (6)), which is the exponential result of $\xi$, as previously described. It is note that this model was used to estimate the three forms of student performance measurement (FP, PGF and PSC):

$$
\begin{aligned}
& \mu_{i}= \\
& \beta_{0}+\beta_{1} \text { CUniv }+\beta_{2} \text { College }+\beta_{3} \text { IF }+\beta_{4} \text { University }+\beta_{5} \text { Northeast }+ \\
& \quad \beta_{6} \text { Southeast }+\beta_{7} \text { South }+\beta_{8} \text { Central }- \text { West }+\beta_{9} D L+\beta_{10} \text { Afternoon }+ \\
& \quad \beta_{11} \text { Full }- \text { time }+\beta_{12} \text { Nocturnal }
\end{aligned}
$$

$$
\begin{aligned}
\log \left(\sigma_{i}\right) & =\beta_{0}+\beta_{1} \text { CUniv }+\beta_{2} \text { College }+\beta_{3} \text { IF }+\beta_{4} \text { University }+\beta_{5} \text { Northeast }+ \\
& +\beta_{6} \text { Southeast }+\beta_{7} \text { South }+\beta_{8} \text { Central }- \text { West }+\beta_{9} D L+\beta_{10} \text { Afternoon }+ \\
& +\beta_{11} \text { Full }- \text { time }+\beta_{12} \text { Nocturnal }
\end{aligned}
$$

$v_{i}=$

$$
\begin{aligned}
& \beta_{0}+\beta_{1} \text { CUniv }+\beta_{2} \text { College }+\beta_{3} \text { IF }+\beta_{4} \text { University }+\beta_{5} \text { Northeast }+ \\
& \quad+\beta_{6} \text { Southeast }+\beta_{7} \text { South }+\beta_{8} \text { Central }- \text { West }+\beta_{9} \text { DL }+\beta_{10} \text { Afternoon }+ \\
& \quad+\beta_{11} \text { Full }- \text { time }+\beta_{12} \text { Nocturnal }
\end{aligned}
$$

$$
\xi_{0}=\frac{\exp (\xi)}{1+\exp (\xi)}
$$

It is also appropriate to point out that the reference categories (baseline) of the variables AO, REG, MOD and SHI are, respectively, the following: Cefet, North, In-Person and Morning. To evaluate the quality of the adjustments of the three zero adjusted BCCG regression models, we examined the randomized quantile residuals (Dunn \& Smyth, 1996). Through the graph of residuals vs. predicted, it was found that the model was adequate to the data, since the residuals were distributed homogeneously around zero. In addition, the quantile-quantile graph (QQplot) showed no major deviations from the distribution of the residuals, in relation to the Normal distribution, indicating adequate adjustment of the BCCG distribution and the model to the data. For more details, see the Appendix A. The level of significance adopted was $5 \%$ and the analyses were performed in software R version 4.0.2 (R Core Team, 2020) and SAS version 9.4 (SAS Institute, 1996).

\section{RESULTS}

\subsection{Results of the regression models}

Table Table 4the result of the zero adjusted BCCG regression model for the parameter $\left(\mu_{\mathbf{i}}\right)$ whose dependent variable is FP. It is noted that, apart from the parameter associated to the SHI - Afternoon category, the others were significant $(\mathrm{p}<0.05)$. In the case of the variable AO, it is observed that, compared to the grade of students of Cefets, the grades of students from university centers, colleges, federal institutes, and universities are relevantly lower on average, in $13.38,15.92,10.55$ and 12.54 points, respectively. 
Table 4

Result OF the zero adjusted BCCG model $\left(\left(\mu_{i}\right)\right.$ parameter $)$ for FP

\begin{tabular}{|c|c|c|c|c|}
\hline FP & Estimate & Standard error & Statistics $t$ & P-value \\
\hline (Intercept) & 53,18 & 1,30 & 40,87 & $<0.0001$ \\
\hline $\mathrm{AO}-\mathrm{CUniv}$ & $-13,38$ & 1,28 & $-10,38$ & $<0.0001$ \\
\hline AO-College & $-15,92$ & 1,28 & $-12,36$ & $<0.0001$ \\
\hline $\mathrm{AO}-\mathrm{IF}$ & $-10,55$ & 1,37 & $-7,67$ & $<0.0001$ \\
\hline AO - University & $-12,54$ & 1,28 & $-9,74$ & $<0.0001$ \\
\hline REG - Northeast & 0,88 & 0,17 & 5,15 & $<0.0001$ \\
\hline REG - Southeast & 2,33 & 0,16 & 14,61 & $<0.0001$ \\
\hline REG - South & 2,42 & 0,16 & 14,31 & $<0.0001$ \\
\hline REG - Central-West & 0,69 & 0,19 & 3,57 & $<0.0001$ \\
\hline MOD - DL & $-6,36$ & 0,09 & $-67,32$ & $<0.0001$ \\
\hline SHI - Afternoon & $-0,20$ & 0,36 & $-0,58$ & 0,56 \\
\hline SHI - Full-time & 2,96 & 0,19 & 15,47 & $<0.0001$ \\
\hline SHI - Night & $-2,68$ & 0,13 & $-20,08$ & $<0.0001$ \\
\hline$\xi_{0}=\boldsymbol{P}(\boldsymbol{Y}=\mathbf{0})$ & $-6,97$ & 0,08 & $-83,11$ & $<0.0001$ \\
\hline
\end{tabular}

Note. For the table of estimation of scale parameters $\left(\log \left(\sigma_{i}\right)\right)$ and shape $\left(v_{i}\right)$, please refer to Appendix B.

For the region, it was verified that the grades of students from the North region (baseline) were significantly lower, on average, than the grades of students from the Northeast, Southeast, South and Central-West regions in 0.88, 2.33, 2.42 and 0.69 points, respectively. Regarding the modality, it is observed that the students of the DL obtained worse scores than those of the faceto-face. Specifically, the score of those was, on average, lower than their score in 6.36 points. Finally, students whose shift is full-time obtained, on average, 2.96 points more than the students of the morning shift. On the other hand, students of the night course took 2.68 points less in the Enade than those of the morning. And there was no significant difference between the performance of the students of the morning and the afternoon shifts $(p>0.05)$.

Table Table 5the result of the zero adjusted BCCG model relative to the parameter $\left(\mu_{\mathbf{i}}\right)$ whose dependent variable is PGF. Except for the parameters of the categories AO - IF and REG - Northeast, REG - Southeast and SHI - Afternoon, the rest presented significance ( $p<0.05$ ). For the $\mathrm{AO}$ variable, it is considered that the grade of students from university centers, colleges and universities is lower than that of students of Cefets, given that the estimates are negative. More specifically, Cefet students (reference category) obtained, on average, 13.56, 16.05, 10.23 and 11.54 points more than students enrolled in university centers, colleges, IFs and universities, respectively. Supplemental to the previous literature, this finding derived from the comparison between the multiple forms of academic structuring emphasizes its relevance for student performance purposes. Future studies may expand this line of analysis with this significant result in mind.

Table 5

\section{Result of the zero adjusted BCCG model $\left(\left(\mu_{i}\right)\right.$ parameter) to the PGF}

\begin{tabular}{lcccc}
\hline PGF & Estimate & Standard error & Statistics $\boldsymbol{t}$ & P-value \\
\hline (Intercept) & 59,93 & 4,28 & 14,00 & $<0.0001$ \\
AO - CUniv & $-13,56$ & 4,27 & $-3,17$ & $<0.0001$ \\
AO - College & $-16,05$ & 4,27 & $-3,76$ & $<0.0001$ \\
AO - IF & $-10,23$ & 4,31 & $-2,37$ & 0,02 \\
AO - University & $-11,54$ & 4,27 & $-2,70$ & $<0.0001$ \\
REG - Northeast & 0,19 & 0,23 & 0,82 & 0,41 \\
REG - Southeast & 0,54 & 0,22 & 2,45 & 0,01 \\
& & & & \\
\hline
\end{tabular}




\begin{tabular}{lcccc} 
REG - South & 0,99 & 0,23 & 4,27 & $<0.0001$ \\
REG - Central-West & $-1,08$ & 0,27 & $-4,03$ & $<0.0001$ \\
MOD - DL & $-5,28$ & 0,12 & $-42,30$ & $<0.0001$ \\
SHI - Afternoon & 0,36 & 0,47 & 0,77 & 0,44 \\
SHI - Full-time & 3,11 & 0,25 & 12,64 & $<0.0001$ \\
SHI - Night & $-3,59$ & 0,17 & $-20,67$ & $<0.0001$ \\
\hline$\xi_{0}=\boldsymbol{P}(\boldsymbol{Y}=\mathbf{0})$ & $-5,57$ & 0,04 & $-133,80$ & $<0.0001$ \\
\hline
\end{tabular}

Note. For the table of estimation of scale parameters $\left(\log \left(\sigma_{i}\right)\right)$ and shape $\left(v_{i}\right)$, please refer to Appendix B.

In relation to the region, it is found that students from the Southeast and South regions had, on average, 0.54 and 0.99 points more than those from the North region in general formation issues. Students from the Northeast region performed similarly to those in the North region $(p>0.05)$. In addition, students from the Central-West region took, on average, 1.08 points less than those from the North region. Even though, in general, the students from the Central-West region had a better final performance (see Table 4), they were surpassed by students from the Northern region in general education (PGF) issues. This analysis allows us to observe that students from the Central-West region can improve their knowledge of general training to achieve the performances of students from other regions.

Regarding the teaching modality, the students of the DL took 5.28 points less than the ones in the classroom, resembling the analysis of the FP. And for the shift, it was found that the full-time students scored, on average, 3.11 points more than those from the morning shift. In contrast, night shift students performed 3.59 points less in the general formation test of Enade compared to those from the morning shift. There was no statistically relevant difference between the performance of students of the morning and afternoon shifts $(\mathrm{p}>0.05)$.

Table Table 6 shows the result of the zero adjusted BCCG model referring to the parameter $\left(\mu_{\mathbf{i}}\right)$ whose dependent variable is the PSC. Except for the parameters associated with the SHI - Afternoon category, the others presented significance $(\mathrm{p}<0.05)$. In the specific component test, students from university centers, colleges, federal institutes, and universities obtained average grades lower than those of Cefets in 12.27, 14.87, 9.54 and 11.74 points, respectively.

Table 6

Result of the zero adjusted BCCG model $\left(\left(\mu_{i}\right)\right.$ parameter $)$ for PSC

\begin{tabular}{|c|c|c|c|c|}
\hline PSC & Estimate & Standard error & Statistics $t$ & P-value \\
\hline (Intercepto) & 50,04 & 1,41 & 35,59 & $<0.0001$ \\
\hline $\mathrm{AO}-\mathrm{CUniv}$ & $-12,27$ & 1,39 & $-8,82$ & $<0.0001$ \\
\hline $\mathrm{AO}-$ College & $-14,87$ & 1,39 & $-10,69$ & $<0.0001$ \\
\hline $\mathrm{AO}-\mathrm{IF}$ & $-9,54$ & 1,48 & $-6,45$ & $<0.0001$ \\
\hline $\mathrm{AO}$ - University & $-11,74$ & 1,39 & $-8,45$ & $<0.0001$ \\
\hline REG - Northeast & 1,20 & 0,19 & 6,35 & $<0.0001$ \\
\hline REG - Southeast & 2,95 & 0,18 & 16,60 & $<0.0001$ \\
\hline REG - South & 2,90 & 0,19 & 15,48 & $<0.0001$ \\
\hline REG - Central-West & 1,38 & 0,22 & 6,39 & $<0.0001$ \\
\hline MOD - DL & $-6,80$ & 0,10 & $-65,65$ & $<0.0001$ \\
\hline SHI - Afternoon & $-0,37$ & 0,40 & $-0,94$ & 0,35 \\
\hline SHI - Full-time & 2,92 & 0,21 & 14,09 & $<0.0001$ \\
\hline SHI - Night & $-2,46$ & 0,15 & $-16,95$ & $<0.0001$ \\
\hline$\xi_{0}=\boldsymbol{P}(\boldsymbol{Y}=\mathbf{0})$ & $-6,29$ & 0,06 & $-105,50$ & $<0.0001$ \\
\hline
\end{tabular}

Note. For the table of estimation of scale parameters $\left(\log \left(\sigma_{i}\right)\right)$ and shape $\left(v_{i}\right)$, please refer to Appendix B. 
For the region, it was found that students from the North region (baseline) obtained lower grades than in other regions. Specifically, the average score of students from the North region was lower than that of students from the Northeast, Southeast, South and Central-West regions in $1.20,2.95,2.90$ and 1.38 points, respectively. In addition, DL students took, on average, 6.80 points less than those in-person. Thus, the evidence related to the modality of teaching of this research reinforces the view that students of face-to-face education have higher performance than those of the DL. And finally, while full-time students took, on average, 2.92 points more than those from the morning, those from the night took 2.46 points less than those in the morning. Students from the afternoon period played as well as those from the morning, which showed no statistically material difference $(\mathrm{p}>0.05)$.

\subsection{Discussion of findings}

In this subsection, the results are discussed with the previous literature, bearing in mind the hypotheses formulated. Hypothesis 1 predicted that there is a significant difference between the performance of students enrolled in the different forms of academic organization. According to the results, hypothesis 1 was sustained. It was possible to verify significant differences in performance in the five categories from the AO variable. For the three forms of performance measurement (FP, PGF and PSC), the best score was obtained by Cefet students, followed by those of IFs, universities, university centers and colleges. Since HEIs can be organized academically in different ways, it is important that future studies investigate in detail which characteristics are the most influential in the performance of their students.

The results of the present study are opposed to those of Bervian and Corrêa (2015) in the sense that they did not find relevant differences between the performance of students enrolled in universities, colleges, and university centers. On the other hand, the findings of Caetano et al. (2015) shows that there is a significant difference between the performance of students from universities and other forms of academic organization (non-university). Those (university students) got better performances than these (non-university ones). Furthermore, the work of Santos (2012) points out that for "Provão 2002" the academic organization was not a relevant variable to explain student performance. However, in "Provão 2003" and "Enade 2006", it was significant, favoring students enrolled in universities and university centers. Unlike previous studies that grouped the categories of academic organization, the present paper analyzes the categories in isolation, providing more specific findings. A new finding refers to Cefet, little mentioned in the literature consulted and whose students presented the best performance according to the analyses of this paper. Nevertheless, it is reported that this finding should be viewed with caution due to the low number of observations. Even so, it is a point that deserves further deepening and that raises some questions, such as: what are Cefet's incentive policies so that students feel more motivated when doing Enade? What are different pedagogical practices instructors are using in Cefet? Baldo (2018) points out that Cefets work in post-secondary professional education aiming at professional qualification at multiple levels of education and they make use of the different modalities of teaching available. Does this type of qualification or vocational education have fundamentally different characteristics from traditional undergraduate courses in Administration and Accounting? If so, which characteristics and why do they affect performance more positively than in other types of academic organization? Future studies may take a closer look at Cefets to answer such questions.

Hypothesis 2 determines that the North and Northeast regions are negatively associated with academic performance. The results of this research offer partial support to H2. The North region, among all regions, presented the worst final performance (FP) and the worst performance in the specific component test (PSC). The only situation in which the Northern region obtained 
the best score was in the case of the general formation test (PGF) in relation to the Central-West. Taken together, these findings corroborate what was predicted by $\mathrm{H} 2$. However, the Northeast region obtained a higher score than the Central-West on the final performance (FP) and performance in the general formation test (PGF). The Central-West surpassed the Northeast only in the specific component issues (PSC). Therefore, the Northeast region was only behind the South and Southeast regions.

Data from "PNAD Continuada - Educação 2019" (IBGE, 2019) show multiple educational topics in which the Northeast region is deficient in relation to the other ones. The data analyzed by Santos et al. (2014) indicate that the ten states with the lowest per capita income belong to the North and Northeast regions. Despite these economic, social, and educational differences between the regions, the Northeast still managed to overcome the Central-West. For this reason, the Northeast region does not seem to be associated with a note as negative as one might think and, consequently, $\mathrm{H} 2$ is only partially sustained. In short, as a general rating (FP), the performance leadership was on the South region, followed by the Southeast, Northeast, Central-West and North regions. This result is consistent with those from Mallmann et al. (2021), Santos (2012) and Brandt et al. (2020), which showed the South and Southeast regions outnumbered the others. On the other hand, it differs from the study by Nasu and Sasso (2021), which identified the best performance from the Northeast region, followed by the Southeast, North, Central-West and South. This result differentiation may be associated with the courses considered in the research analyses. The present work included only students of Accounting Sciences and Administration, while Nasu and Sasso (2021) included, in addition to these, Economics, Executive Secretariat and Tourism.

Hypothesis 3 establishes that there is a positive relationship between classroom teaching and academic performance. The results for the three forms of performance measurement offer strong support for H3. The students of the in-person education scored, on average, 6.36, 5.28 and 6.80 points more than those from DL in the case of FP, PGF and PSC, respectively. This evidence suggest that the face-to-face modality is of superior quality compared to the distance format. The biggest discrepancy lies in the PSC (6.80 points difference), indicating that students of accounting sciences and administration from DL need greater attention and assistance in the specific component issues. That is, in those contents that are specific to their professions.

The discoveries of this study support the questioning by researchers about the quality of DL (Alonso, 2010; Bertolin, 2021), besides being compatible with the result of Caetano et al. (2015). Additionally, they reinforce the view of employers about the preference for hiring employees who have taken the undergraduate course in person (Grossman \& Johnson, 2016), given that these have performed better than those of the DL. Despite the low performance of the students from DL, the present work does not suggest that this modality should be discontinued. It's better if there's an option for the DL than to extinguish it. However, this does not exclude one from questioning its quality. It is legitimate for society and academic agents to continue, constantly, questioning and charging higher quality educational services both in the DL and in the face-to-face. The Covid-19 pandemic caused face-to-face teaching to migrate to remote education, which is also subject to criticism of educational quality, mainly because the transition from in-person to remote was made in an emergency and some professors may not have had enough and appropriate preparation to deal with technological teaching equipment. On the other hand, with the adoption of remote education, everyone began to learn remotely, which can reduce the level of preference for hiring people who took the courses in person.

Hypothesis 4 defines that the full shift is positively associated with academic performance. The results corroborate $\mathrm{H} 4$ by showing that full-time students obtained the best grades in the three types of performance. It was also possible to observe, for the three performances, that there was no statistically significant difference in performance between the 
students of the morning and afternoon shifts. The students from the night shift, however, presented significantly lower scores than those in the morning in the three forms of performance measurement, with special attention to the general education score in which there was the largest difference (3.59 points).

The result of this work is compatible with the hypothetical expectation because full-time students have more study time than others who have partial dedication. The finding is consistent with the research of Mallmann et al. (2021), who also found that the full shift had the best academic performance. In the case of Farias et al. (2015), the full-time shift was not an option. But it was found that the students of the day shift (morning and afternoon) performed better than the students of the night. Students from the night courses tend to work all day (Cornachione Junior et al., 2010), and might be more tired when they come to class which potentially lowers the level of attention. Many students work for their own livelihood or for their family, having as their only alternative the night course (Moura et al., 2015). For this reason, it is particularly recommended that professors of night courses use active teaching methodologies with the purpose of promoting greater involvement of students in classes.

\section{FINAL CONSIDERATIONS}

The objective of this research was to analyze the association between institutional variables (academic organization, region, modality and shift) and academic performance (final performance, performance in the general formation test and performance in the specific component test) of students in the business area (Administration and Accounting). The microdata related to the edition of "Enade 2018" were collected, obtaining 152,491 valid observations. The data were examined using zero adjusted BCCG regression models, which did not present adjustment problems, as suggested by the diagnostic analyses. Thus, it is pointed out that this form of modeling is a candidate to be used in future studies that present data with similar characteristics to those of this study.

From the results, it was concluded that the institutional variables were relevant to explain the students' performance. It was observed that, in general, students enrolled in Cefets had superior performance than universities, university centers, colleges and IFs. Another point was that, for the final performance, the students from the North region performed worse than that of the other regions. However, when analyzing by type of content, it was found that the students from the North region surpassed those from the Central-West region in general formation issues. Regarding the teaching modality, it was found that students from the classroom teaching presented higher performance than the DL students. And full-time students performed better overall.

This study has implications for students, faculty and HEIs. In the case of students, the findings contribute to a better decision-making when choosing the HEI and the form of learning. To maximize academic performance in Enade, it is recommended that the student chooses the modality of classroom teaching, full-time, the South region and the Cefet. It is worth noting this last variable of HEI should be viewed with caution since there were few observations that studied in Cefets compared to the other ones. Therefore, the student must research and align their objectives with the academic organization of the HEI, prioritizing those of superior quality and reputation.

For faculty, the comparative analyses of this study may promote greater encouragement for improvement of teaching. For instance, it was found that students in the classroom have better performances than those in the DL. In this sense, DL instructors may want to make additional materials available, include more optional subjects, consider new strategies and teaching equipment in classes with the aim of raising the quality of education for future 
Accountants and Administrators. In addition, it was said that the Central-West region had the worst performance in general formation issues. Therefore, it is vital that the instructors of accounting and administration courses from the Central-West who teach matters of general competences (e.g., communication, text interpretation, professional ethics, entrepreneurship) adopt new and different pedagogical approaches to strengthen the knowledge of general formation of students to increase their performance. It was also found that the students of the night shift obtained the worst performances. Cornachione Junior et al. (2010) pointed out that these students typically work throughout the day, which can lead them to a higher level of fatigue when attending classes at night. In this sense, it is suggested to instructors who work at night the use of active teaching methodologies, which have the potential for strong involvement of the student in the learning process.

For HEIs, this study has two serious implications. First, it is imperative to recognize that students performed poorly in Enade. As shown in Table 2, the final average performance was 37.88 points on a scale of 0.00 to 100.00 points. In possession of this result, in addition to improving teaching, HEIs may want to implement policies that encourage students to perform better, such as granting additional credits or hours of complementary activity to those who achieve a minimum grade on the grounds that it was necessary to dedicate some extra study time for Enade. As discussed in the Introduction, student performance in Enades is one of the criteria for classifying the quality of HEIs. By motivating its students, the HEIs can benefit from having its grade increased, which in turn elevates its reputation before the market and society. Second, by highlighting the categories that reduce student performance, HEIs can direct resources for their improvement. HEIs located in the North region or having campus in this region might want to invest more in their facilities, their materials and in the qualification of their faculty, since the performance of their students was the lowest compared to the other regions. Likewise, the HEIs may want to offer full-time accounting and administration courses, since the students from this shift obtained better grades compared to the others. It is warned, however, that this offer should be carefully considered because it may involve relevant costs.

This research has limitations that deserve to be described. The first is there is little research on the relationship between the academic organization of HEIs and student performance (Miranda et al., 2015). Therefore, it is recognized that the theoretical discussion has become more restricted in this sense. The second limitation is that some institutional variables showed unbalanced frequency of their categories, such as AO - Cefet, AO - IF and SHI - Afternoon. In this regard, it is reported that the regression models remained adequate. The third limitation is the use of data for the year 2018. Since then, the educational scenario has undergone significant changes, mainly due to the Covid-19 pandemic. Nevertheless, it is emphasized that Enade 2018 was the last edition conducted by students of accounting sciences and administration whose data are available.

As recommendations for future research, it is suggested, in addition to those carried out throughout the work, the following: (i) inclusion of other institutional variables in the models; (ii) analysis of the relation between institutional variables and student performance by type of question (e.g., open-ended vs. objective) and program content (e.g., cost accounting, corporate accounting, financial management, etc.) contained in the business courses curricula; and (iii) examination of academic performance when there is a change of institutional variable. By way of illustration, when a college student starts studying at a university or when a student from the South starts studying in the Southeast region. 


\section{REFERENCES}

Ahinful, G. S., Tauringana, V., Bansah, E. A., \& Essuman, D. (2019). Determinants of academic performance of accounting students in Ghanaian secondary and tertiary education institutions. Accounting Education, 28(6), 553-581. https://doi.org/10.1080/09639284.2019.1679204

Alonso, K. M. (2010). A expansão do ensino superior no Brasil e a EaD: dinâmicas e lugares. Educação \& Sociedade, 31, 1319-1335. https://doi.org/10.1590/S0101-73302010000400014

Andreoli, C. P. P., \& De Martino, M. M. F. (2012). Academic performance of night-shift students and its relationship with the sleep-wake cycle. Sleep Science, 5(2), 45-48. Recuperado de http://sleepscience.org.br/details/55/en-US/academic-performance-of-nightshift-students-and-its-relationship-with-the-sleep-wake-cycle

Baldo, G. C. (2018). Educação superior brasileira: organização acadêmica. Revista Científica Eletrônica do Curso de Direito, 14, 1-21. Recuperado de http://faef.revista.inf.br/imagens_arquivos/arquivos_destaque/wkAntfKsLYEcp33_2019-228-15-25-49.pdf

Beatson, N., Gabriel, C.-A., Howell, A., Scott, S., van der Meer, J., \& Wood, L. C. (2020). Just opt in: How choosing to engage with technology impacts business students' academic performance. Journal of Accounting Education, $50,100641$. https://doi.org/10.1016/j.jaccedu.2019.100641

Bertolin, J. C. G. (2021). Existe diferença de qualidade entre as modalidades presencial e a distância? Cadernos de Pesquisa, 51, e06958. https://doi.org/10.1590/198053146958

Bervian, L. M., \& Corrêa, M. (2015). ENADE: Impactos da categoria administrativa, organização acadêmica e número de participantes no desempenho dos estudantes. Revista de Administração Educacional, $1(2), \quad 6-27 . \quad$ Recuperado de https://periodicos.ufpe.br/revistas/ADED/article/viewFile/2475/2003

Brandt, J. Z., Tejedo-Romero, F., \& Araujo, J. F. F. E. (2020). Fatores influenciadores do desempenho acadêmico na graduação em administração pública. Educação e Pesquisa, 46, e202500. https://doi.org/10.1590/s1678-4634202046202500

Byrne, M., \& Flood, B. (2008). Examining the relationships among background variables and academic performance of first year accounting students at an Irish University. Journal of Accounting Education, 26(4), 202-212. https://doi.org/10.1016/j.jaccedu.2009.02.001

Caetano, C., Cardoso, T., Miranda, G., \& Freitas, S. (2015). Academic performance in accounting: online versus traditional education. Revista Universo Contábil, 11(4), 147-165. https://doi.org/10.4270/ruc.2015436

Cheng, C., Sapkota, P., \& Yurko, A. J. N. (2021). A Case Study of Effective Tax Rates Using Data Analytics. Issues in Accounting Education, 36(1), 65-89. https://doi.org/10.2308/ISSUES-19-060 
Cornachione Junior, E. B., Cunha, J. V. A. da, De Luca, M. M. M., \& Ott, E. (2010). O bom é meu, o ruim é seu: perspectivas da teoria da atribuição sobre o desempenho acadêmico de alunos da graduação em Ciências Contábeis. Revista Contabilidade \& Finanças, 21(53), 1-24. https://doi.org/10.1590/S1519-70772010000200004

Dunn, P. K., \& Smyth, G. K. (1996). Randomized Quantile Residuals. Journal of Computational and Graphical Statistics, 5(3), 236-244. https://doi.org/10.2307/1390802

ElKelish, W. W., \& Ahmed, R. (2021). Advancing accounting education using LEGO® Serious Play simulation technique. Accounting Education, 1-17. https://doi.org/10.1080/09639284.2021.1905011

Farias, M. R. S., Alves, F. de S., \& Farias, K. T. R. (2015). Desempenho acadêmico em métodos quantitativos nos cursos de Ciências Contábeis. Enfoque: Reflexão Contábil, 34(2), 37-50. https://doi.org/10.4025/enfoque.v34i2.26818

Fogarty, T. J., Zimmerman, A. B., \& Richardson, V. J. (2016). What do we mean by accounting program quality? A decomposition of accounting faculty opinions. Journal of Accounting Education, 36, 16-42. https://doi.org/10.1016/j.jaccedu.2016.04.001

Fortin, A., Viger, C., Deslandes, M., Callimaci, A., \& Desforges, P. (2019). Accounting students' choice of blended learning format and its impact on performance and satisfaction. Accounting Education, 28(4), 353-383. https://doi.org/10.1080/09639284.2019.1586553

Francescucci, A., Kellershohn, J., \& Pyle, M. A. (2021). Using Online Class Preparedness Tools to Improve Student Performance: The Benefit of "All-In" Engagement. Journal of Management Education, 45(4), 558-578. https://doi.org/10.1177/1052562920960205

Gracia, L., \& Jenkins, E. (2003). A quantitative exploration of student performance on an undergraduate accounting programme of study. Accounting Education, 12(1), 15-32. https://doi.org/10.1080/0963928032000049375

Grimm, S. D. (2021). Junkyard Planet: Using Stories to Teach Managerial Accounting with a Sustainability Theme. Issues in Accounting Education. https://doi.org/10.2308/ISSUES-19063

Grossman, A. M., \& Johnson, L. R. (2016). Employer Perceptions of Online Accounting Degrees. Issues in Accounting Education, 31(1), 91-109. https://doi.org/10.2308/iace-51229

Grossman, A. M., \& Johnson, L. R. (2017). How employers perceive online accounting education: Evidence from Kentucky. Journal of Accounting Education, 40, 19-31. https://doi.org/10.1016/j.jaccedu.2017.06.002

IBGE. (2019). PNAD Educação 2019, PNAD Contínua. Recuperado de: https://biblioteca.ibge.gov.br/visualizacao/livros/liv101736_informativo.pdf

INEP. (2021). Microdados do Exame Nacional de Desempenho dos Estudantes. Recuperado em 12 agosto, 2021 de https://www.gov.br/inep/pt-br/acesso-a-informacao/dadosabertos/microdados/enade 
Kafaji, M. (2020). The perceived benefits of accreditation on students' performance: The case of private business schools. Industry and Higher Education, 34(6), 421-428. https://doi.org/10.1177/0950422220902698

Kuang, T. M., Adler, R. W., \& Pandey, R. (2021). Creating a Modified Monopoly Game for Promoting Students' Higher-Order Thinking Skills and Knowledge Retention. Issues in Accounting Education, 36(3), 49-74. https://doi.org/10.2308/ISSUES-2020-097

Madsen, P. E. (2020). Research Initiatives in Accounting Education: Transforming Today's Students into Accounting Professionals. Issues in Accounting Education, 35(4), 35-46. https://doi.org/10.2308/ISSUES-2020-016

Mallmann, C., Nasu, V., \& Domingues, M. J. (2021). Relação entre a leitura de livros e o desempenho acadêmico: análise com discentes de ciências sociais aplicadas. Revista de Educação e Pesquisa Em Contabilidade (REPeC), 15(2), 163-184. https://doi.org/10.17524/repec.v15i2.2751

McCarthy, M., Kusaila, M., \& Grasso, L. (2019). Intermediate accounting and auditing: Does course delivery mode impact student performance? Journal of Accounting Education, 46, 2642. https://doi.org/10.1016/j.jaccedu.2018.12.001

Miglietti, C. (2021). Student performance in accounting courses: Do bonus points motivate performance? Journal of Education for Business, 96(4), 237-242. https://doi.org/10.1080/08832323.2020.1812486

Miranda, G. J., Lemos, K. C. da S., Oliveira, A. S. de, \& Ferreira, M. A. (2015). Determinantes do Desempenho Acadêmico na Área de Negócios. Revista Meta: Avaliação, 7(20), 175-209. https://doi.org/10.22347/2175-2753v7i20.264

Moura, A. C. da R., Miranda, G. J., \& Pereira, J. M. (2015). Desempenho acadêmico em ciências contábeis: turno noturno versus diurno. Enfoque: Reflexão Contábil, 34(1), 57-70. https://doi.org/10.4025/enfoque.v34i1.23020

Nakos, G., \& Whiting, A. (2018). The role of frequent short exams in improving student performance in hybrid global business classes. Journal of Education for Business, 93(2), 5157. https://doi.org/10.1080/08832323.2017.1417231

Namin, A., Ketron, S. C., Kaltcheva, V. D., \& Winsor, R. D. (2021). Improving Student Presentation Skills Using Asynchronous Video-Based Projects. Journal of Management Education, 45(6), 987-1010. https://doi.org/10.1177/1052562920978805

Nasu, V. H. (2020). Accounting students' performance in distance education: a study focused on sociodemographic factors. Journal of Information Systems and Technology Management, 17, e202017007. https://doi.org/10.4301/S1807-1775202017007

Nasu, V. H., \& Sasso, M. (2021). A Bolsa faz Diferença? Uma Análise do Desempenho Acadêmico de Alunos Bolsistas de Cursos de Graduação da Área de Negócios. Arquivos 
$\begin{array}{llll}\text { Analíticos de } \quad \text { Políticas } & \text { Educativas, } & \text { 29(99), } & \text { 1-24. }\end{array}$ https://doi.org/https://doi.org/10.14507/epaa.29.5896

Nsor-Ambala, R. (2020). Impact of exam type on exam scores, anxiety, and knowledge retention in a cost and management accounting course. Accounting Education, 29(1), 32-56. https://doi.org/10.1080/09639284.2019.1683871

Pike, G. R. (1991). The effects of background, coursework, and involvement on students' grades and satisfaction. Research in Higher Education, 32(1), 15-30. https://doi.org/10.1007/BF00992830

R Core Team. (2020). R: a language and environment for statistical computing. Vienna, AT: R Foundation for Statistical Computing.

Rigby, R., Stasinopoulos, M. D., Heller, G. Z., \& De Bastiani, F. (2019). Distributions for modeling location, scale, and shape: Using GAMLSS in R. Chapman \& Hall/CRC The $\mathrm{R}$ Series.

Rodrigues, B., Miranda, G., Resende, M., \& Pereira, J. (2016). Determinantes do desempenho acadêmico dos alunos dos cursos de Ciências Contábeis no ensino à distância. Enfoque: Reflexão Contábil, 35(2), 139-153. https://doi.org/10.4025/enfoque.v35i2.30105

Santos, N. A. (2012). Determinantes do desempenho acadêmico dos alunos dos cursos de ciências contábeis. [Tese de doutorado, Faculdade de Economia, Administração e Contabilidade da Universidade de São Paulo]. Biblioteca Digital USP. https://doi.org/10.11606/T.12.2012.tde-11062012-164530

Santos, G. R., Pales, R. C., \& Rodrigues, S. G. (2014). Desigualdades regionais no Brasil 1991-2010. InterSciencePlace - Revista Científica Internacional, 31(1), Artigo 6. https://doi.org/10.6020/1679-9844/3106

SAS Institute. (1996). Statistical Analysis System Institute (Cary, \& NC).

Soares, J. (2004). O efeito da escola no desempenho cognitivo de seus alunos. Revista Iberoamericana sobre Calidad, Eficacia y Cambio em Educación, 2(2), 83-104. Recuperado de: https://revistas.uam.es/reice/article/view/5550

Stasinopoulos, D. M., Enea, M., \& Rigby, R. A. (2017). Zero adjusted distributions on the positive real line. Recuperado de http://www.gamlss.com/wpcontent/uploads/2018/01/ZeroAdjustedDistributions.pdf

Stasinopoulos, D. M., Rigby, R., Voudouris, V., Akantziliotou, C., Enea, M., \& Kiose, D. (2021). Package 'gamlss.' CRAN. Recuperado de https://cran.rproject.org/web/packages/gamlss/gamlss.pdf

Stice, E. K., Stice, J. D., \& Albrecht, C. (2020). Study Choices by Introductory Accounting Students: Those Who Study More Do Better and Text Readers Outperform Video Watchers. In Advances in Accounting Education: Teaching and Curriculum Innovations (Vol. 24, pp. 329). https://doi.org/10.1108/S1085-462220200000024007 
Taylor, M., Marrone, M., Tayar, M., \& Mueller, B. (2017). Digital storytelling and visual metaphor in lectures: a study of student engagement. Accounting Education, 1-18. https://doi.org/10.1080/09639284.2017.1361848

Westerman, J. W., Whitaker, B. G., Bergman, J. Z., Bergman, S. M., \& Daly, J. P. (2016). Faculty narcissism and student outcomes in business higher education: A student-faculty fit analysis. The International Journal of Management Education, 14(2), 63-73. https://doi.org/10.1016/j.ijme.2016.02.001

\section{APPENDIX A}

This appendix reports the results of the quality of the adjustment of the regression models to the data.

i) Zero adjusted BCCG model: final performance (FP)

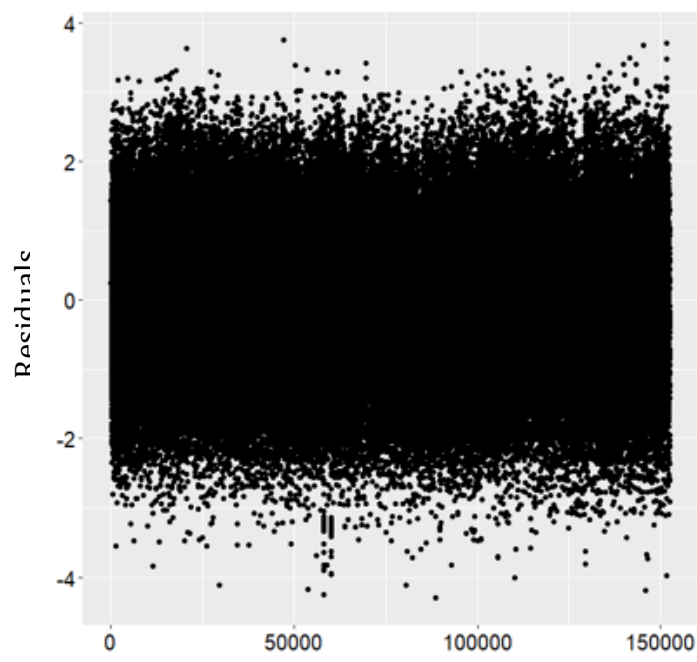

A) Adjusted values vs. randomized quantile residuals

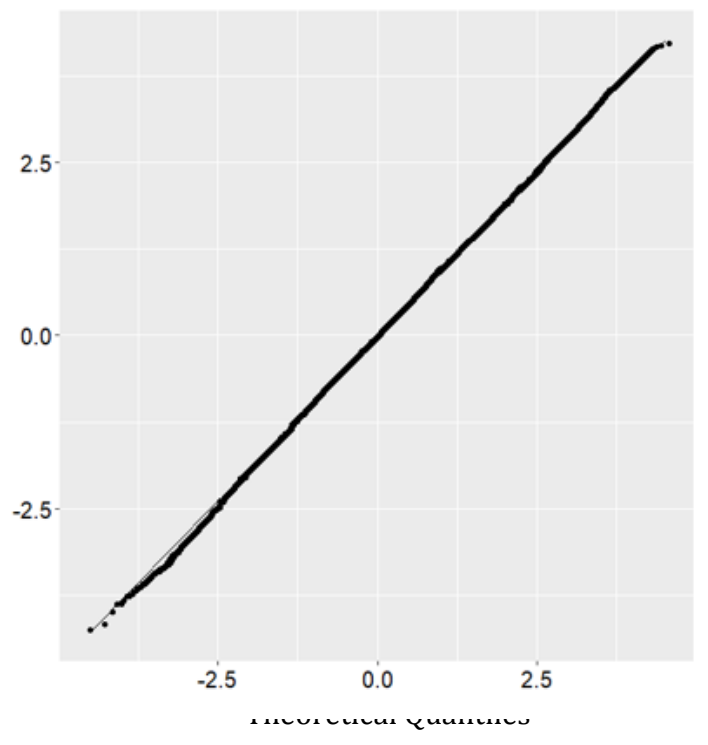

B) QQPlot Chart

(ii) Zero adjusted BCCG model: performance on the general formation test (PGF) 


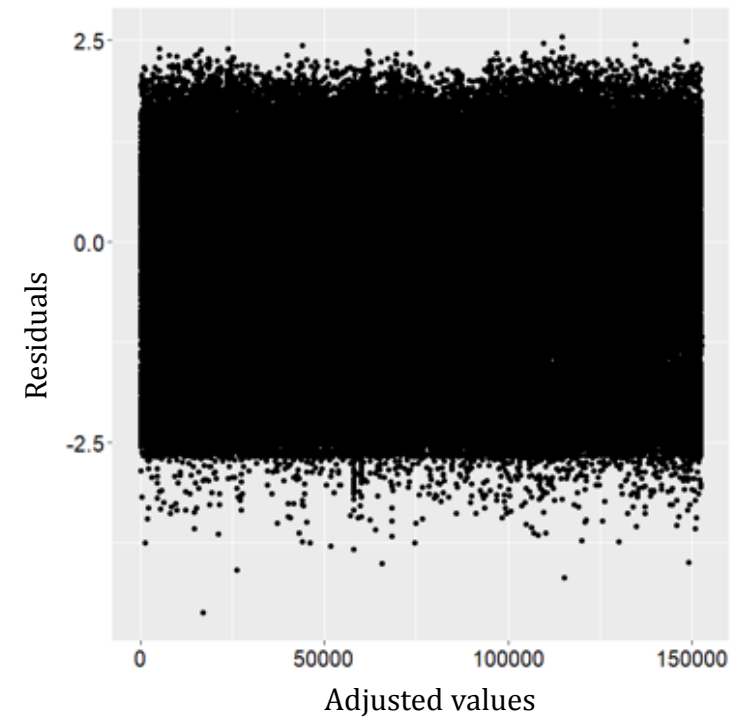

A - Adjusted values vs. randomized quantile residuals

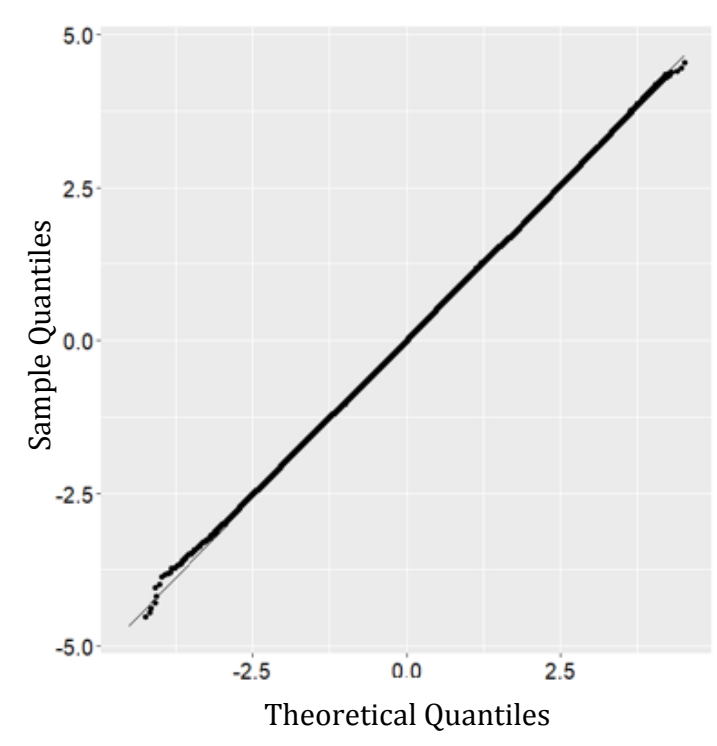

B - QQplot Chart

iii) Zero adjusted BCCG model: performance on the specific component test (PSC)

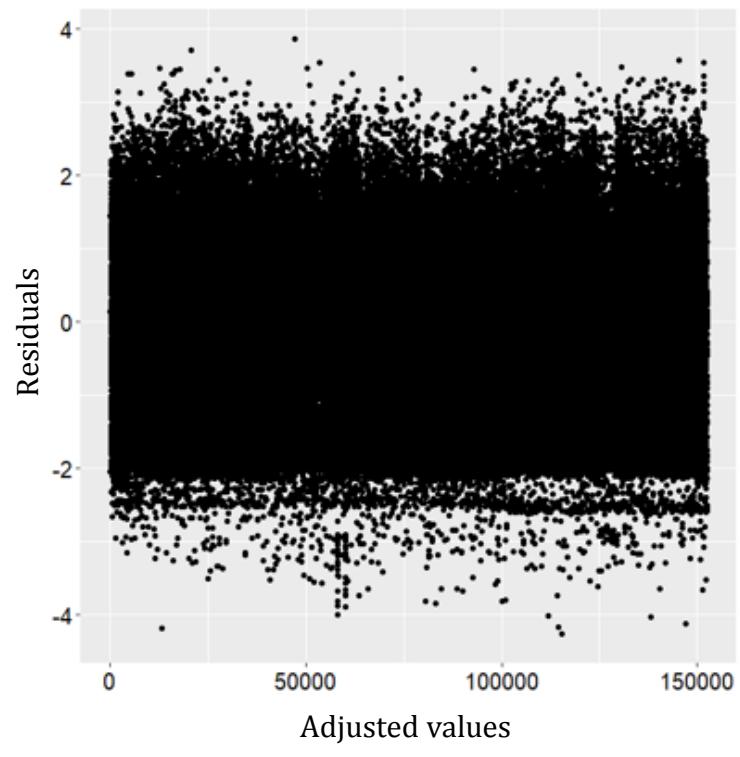

A - Adjusted values vs. randomized quantile residuals

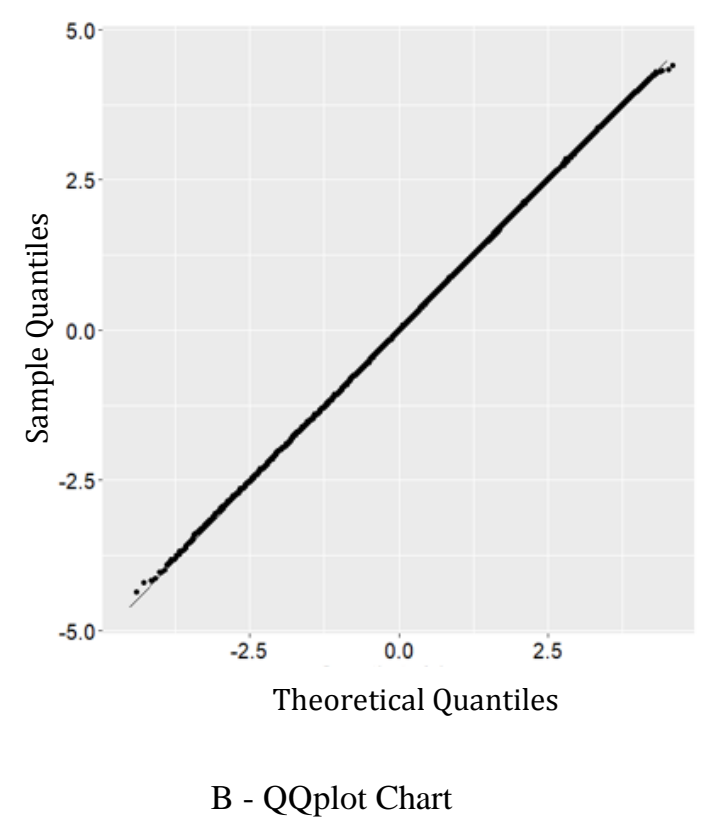




\section{APPENDIX B}

This appendix reports the results of the regression models of the scale $\left(\log \left(\sigma_{i}\right)\right)$ and shape $\left(v_{i}\right)$ parameters, which provide, respectively, indication of potential differences between variances and between the symmetries of performances.

Scale parameter (FP, PGF and PSC)

Result of the zero adjusted BCCG model (parameter $\left(\log \left(\sigma_{i}\right)\right.$ ) for the FP

\begin{tabular}{|c|c|c|c|c|}
\hline FP & Estimate & Standard error & Statistics t & P-value \\
\hline (Intercept) & $-1,4$ & 0,1 & $-20,4$ & $<0,0001 * * *$ \\
\hline $\mathrm{AO}-\mathrm{CUniv}$ & 0,3 & 0,1 & 3,9 & $<0,0001 * * *$ \\
\hline AO - College & 0,3 & 0,1 & 4,0 & $<0,0001 * * *$ \\
\hline $\mathrm{AO}-\mathrm{IF}$ & 0,2 & 0,1 & 2,7 & $<0,0001 * * *$ \\
\hline AO - University & 0,3 & 0,1 & 3,9 & $<0,0001 * * *$ \\
\hline REG - Northeast & 0,0 & 0,0 & 3,1 & $<0,0001 * * *$ \\
\hline REG - Southeast & 0,0 & 0,0 & 2,8 & $<0,0001 * * *$ \\
\hline REG - South & 0,0 & 0,0 & 1,1 & 0,2899 \\
\hline REG - Central-West & 0,0 & 0,0 & 3,4 & $<0,0001 * * *$ \\
\hline MOD - DL & 0,1 & 0,0 & 12,3 & $<0,0001 * * *$ \\
\hline SHI - Afternoon & 0,0 & 0,0 & 0,9 & 0,3752 \\
\hline SHI - Full-time & 0,0 & 0,0 & $-2,0$ & $0,0489 * * *$ \\
\hline SHI - Night & 0,0 & 0,0 & 2,6 & $0,0102 * * *$ \\
\hline
\end{tabular}

Result of the zero adjusted BCCG model (parameter $\left(\log \left(\sigma_{i}\right)\right)$ for the PGF

\begin{tabular}{|c|c|c|c|c|}
\hline PGF & Estimate & Standard error & Statistics $t$ & P-value \\
\hline (Intercept) & $-1,10$ & 0,36 & $-3,07$ & $0,0020 * * *$ \\
\hline $\mathrm{AO}-\mathrm{CUniv}$ & 0,07 & 0,36 & 0,20 & 0,8413 \\
\hline AO-College & 0,10 & 0,36 & 0,28 & 0,7777 \\
\hline $\mathrm{AO}-\mathrm{IF}$ & 0,01 & 0,36 & 0,03 & 0,978 \\
\hline AO - University & 0,05 & 0,36 & 0,14 & 0,8917 \\
\hline REG - Northeast & 0,02 & 0,01 & 1,88 & 0,0606 \\
\hline REG - Southeast & 0,02 & 0,02 & 2,30 & $0,0216^{* * *}$ \\
\hline REG - South & 0,00 & 0,01 & $-0,01$ & 0,9945 \\
\hline REG - Centro-West & 0,06 & 0,01 & 4,60 & $<0,0001 * * *$ \\
\hline MOD - DL & 0,06 & 0,01 & 10,99 & $<0,0001 * * *$ \\
\hline SHI - Afternoon & $-0,01$ & 0,02 & $-0,42$ & 0,678 \\
\hline SHI - Full-time & $-0,04$ & 0,01 & $-3,34$ & $<0,0001 * * *$ \\
\hline SHI - Night & 0,03 & 0,01 & 3,68 & $<0,0001 * * *$ \\
\hline
\end{tabular}

Result of the zero adjusted BCCG model (parameter $\left(\log \left(\sigma_{i}\right)\right)$ for the PSC

\begin{tabular}{|c|c|c|c|c|}
\hline PSC & Estimate & Standard error & Statistics $t$ & P-value \\
\hline (Intercept) & $-1,23$ & 0,07 & $-18,16$ & $<0,0001 * * *$ \\
\hline $\mathrm{AO}-\mathrm{CUniv}$ & 0,23 & 0,07 & 3,48 & $0,0005^{* * *}$ \\
\hline AO-College & 0,25 & 0,07 & 3,78 & $0,0001 * * *$ \\
\hline $\mathrm{AO}-\mathrm{IF}$ & 0,18 & 0,08 & 2,32 & $0,0202 * * *$ \\
\hline AO - University & 0,24 & 0,07 & 3,61 & 0,0003 \\
\hline REG - Northeast & 0,02 & 0,01 & 1,71 & 0,0873 \\
\hline REG - Southeast & 0,00 & 0,01 & $-0,44$ & 0,6637 \\
\hline REG - South & $-0,01$ & 0,01 & $-1,33$ & 0,1842 \\
\hline REG - Central-West & 0,00 & 0,01 & 0,36 & 0,7208 \\
\hline
\end{tabular}




\begin{tabular}{|c|c|c|c|c|}
\hline MOD - DL & 0,09 & 0,01 & 15,71 & $<0,0001 * * *$ \\
\hline SHI - Afternoon & 0,02 & 0,02 & 0,92 & 0,3582 \\
\hline SHI - Full-time & $-0,03$ & 0,01 & $-2,43$ & $0,0149 * * *$ \\
\hline SHI - Night & 0,02 & 0,01 & 2,97 & $0,0029 * * *$ \\
\hline
\end{tabular}

Shape parameter (FP, PGF and PSC)

Result of the zero adjusted BCCG model (parameter $\left(v_{i}\right)$ ) for the FP

\begin{tabular}{|c|c|c|c|c|}
\hline FP & Estimate & Standard error & Statistics $t$ & P-value \\
\hline (Intercept) & 1,20 & 0,35 & 3,48 & $<0,0001 * * *$ \\
\hline $\mathrm{AO}-\mathrm{CUniv}$ & $-0,38$ & 0,34 & $-1,09$ & 0,2737 \\
\hline $\mathrm{AO}-$ College & $-0,44$ & 0,34 & $-1,27$ & 0,2046 \\
\hline $\mathrm{AO}-\mathrm{IF}$ & $-0,19$ & 0,36 & $-0,54$ & 0,5913 \\
\hline AO - University & $-0,36$ & 0,34 & $-1,04$ & 0,297 \\
\hline REG - Northeast & 0,02 & 0,03 & 0,64 & 0,5199 \\
\hline REG - Southeast & 0,02 & 0,03 & 0,52 & 0,6008 \\
\hline REG - South & 0,06 & 0,03 & 1,75 & 0,0809 \\
\hline REG - Central-West & $-0,01$ & 0,04 & $-0,28$ & 0,7815 \\
\hline MOD - DL & $-0,21$ & 0,02 & $-12,78$ & $<0,0001 * * *$ \\
\hline SHI - Afternoon & 0,02 & 0,06 & 0,30 & 0,7633 \\
\hline SHI - Full-time & 0,14 & 0,03 & 4,03 & $<0,0001 * * *$ \\
\hline SHI - Night & $-0,06$ & 0,02 & $-2,40$ & $0,0162 * * *$ \\
\hline
\end{tabular}

Result of the zero adjusted BCCG model (parameter $\left(v_{i}\right)$ ) for the PGF

\begin{tabular}{|c|c|c|c|c|}
\hline PGF & Estimate & Standard error & Statistics $t$ & P-value \\
\hline (Intercept) & 2,59 & 0,55 & 4,72 & $<0,0001 * * *$ \\
\hline $\mathrm{AO}-\mathrm{CUniv}$ & $-1,54$ & 0,55 & $-2,82$ & $0,0048 * * *$ \\
\hline $\mathrm{AO}-$ College & $-1,61$ & 0,55 & $-2,95$ & $0,0031 * * *$ \\
\hline $\mathrm{AO}-\mathrm{IF}$ & $-1,52$ & 0,56 & $-2,73$ & $0,0063 * * *$ \\
\hline AO - University & $-1,49$ & 0,55 & $-2,72$ & $0,0065^{* * *}$ \\
\hline REG - Northeast & 0,02 & 0,04 & 0,58 & 0,5614 \\
\hline REG - Southeast & $-0,05$ & 0,04 & $-1,30$ & 0,1921 \\
\hline REG - South & $-0,01$ & 0,04 & $-0,19$ & 0,8499 \\
\hline REG - Central-West & $-0,05$ & 0,04 & $-1,24$ & 0,2168 \\
\hline MOD - DL & $-0,20$ & 0,02 & $-10,42$ & $<0,0001 * * *$ \\
\hline SHI - Afternoon & $-0,06$ & 0,08 & $-0,72$ & 0,4741 \\
\hline SHI - Full-time & 0,18 & 0,05 & 3,49 & $0,0004 * * *$ \\
\hline SHI - Night & $-0,13$ & 0,03 & $-3,93$ & $<0,0001 * * *$ \\
\hline
\end{tabular}

Result of the zero adjusted BCCG model (parameter $\left(v_{i}\right)$ ) for the PSC

\begin{tabular}{|c|c|c|c|c|}
\hline PSC & Estimate & Standard error & Statistics $t$ & P-value \\
\hline (Intercept) & 0,98 & 0,27 & 3,67 & $<0,0001 * * *$ \\
\hline $\mathrm{AO}-\mathrm{CUniv}$ & $-0,09$ & 0,27 & $-0,36$ & 0,7225 \\
\hline $\mathrm{AO}$ - College & $-0,16$ & 0,27 & $-0,61$ & 0,5416 \\
\hline $\mathrm{AO}-\mathrm{IF}$ & 0,28 & 0,33 & 0,85 & 0,3982 \\
\hline AO - University & $-0,07$ & 0,27 & $-0,25$ & 0,8006 \\
\hline REG - Northeast & 0,05 & 0,03 & 1,75 & 0,0803 \\
\hline REG - Southeast & 0,04 & 0,03 & 1,54 & 0,1229 \\
\hline REG - South & 0,07 & 0,03 & 2,46 & $0,0139 * * *$ \\
\hline REG - Central-West & 0,03 & 0,03 & 0,74 & 0,457 \\
\hline MOD - DL & $-0,19$ & 0,02 & $-12,11$ & $<0,0001 * * *$ \\
\hline SHI - Afternoon & $-0,02$ & 0,07 & $-0,29$ & 0,7701 \\
\hline
\end{tabular}


Vitor Hideo Nasu, Breno Gabriel da Silva, Yana Miranda Borges, Brian Alvarez Ribeiro de Melo

SHI - Full-time

0,11

0,03

3,11

$0,0018^{* * *}$

SHI - Night

$-0,06$

0,02

$-2,68$

$0,0073 * * *$ 